Article

\title{
Proactive Corporate Environmental Responsibility and Financial Performance: Evidence from Chinese Energy Enterprises
}

\author{
Ying Jiang ${ }^{1,2}$, Xiaolong Xue ${ }^{1,3, *}$ and Weirui Xue ${ }^{3}$ \\ 1 School of Management, Harbin Institute of Technology, Harbin 150001, China; jiang89120506@163.com \\ 2 School of Economics, Heilongjiang University of Science and Technology, Harbin 150022, China. \\ 3 School of Management, Guangzhou University, Guangzhou 510006, China; xueweirui@outlook.com \\ * Correspondence: xlxue@hit.edu.cn, +86-186-4500-8236
}

Received: 5 February 2018; Accepted: 21 March 2018; Published: 26 March 2018

\begin{abstract}
With increasing concerns about environmental issues and the advancement of China's "going global" strategy, a new issue-proactive corporate social responsibility has emerged. Proactive corporate environmental responsibility refers to business actions that go beyond regulatory requirements for supporting sustainable environmental development. This study examines the role of proactive corporate environmental responsibility on corporate financial performance in the Chinese energy industry by the multi-variables regression analysis of panel data. Using data of 264 firm-year observations from 2009-2014 in the energy industry, the results showed that Proactive corporate environmental responsibility has a positive effect on corporate financial performance passing the endogeneity test. The results also demonstrate that private ownership has stronger promotion on the relationship between proactive corporate environmental responsibility and corporate financial performance. This study helps to increase the body of knowledge about proactive corporate environmental responsibility of the emerging economy, provides insights into the corporate environmental responsibility practice, and government environmental regulation and policy.
\end{abstract}

Keywords: proactive corporate environmental responsibility; corporate financial performance; ownership; emerging market; energy industry

\section{Introduction}

Practicing environmental responsibility is increasingly significant to firms around the world. Globalization has removed the strict division of environmental responsibility between countries. Correspondingly, more and more firms have started to assume corporate environmental responsibility (CER) that goes beyond legal requirements and fills the global regulatory vacuum. Proactive corporate environmental responsibility (PCER), the environmental dimension of proactive corporate responsibility, represents a pattern of voluntarily responsible practices beyond regulatory requirements to actively support environmental development [1,2].

Environmental issues in China are of concern, both internationally and nationally. China has undergone rapid economic growth and developed a unique hybrid market economy ever since its reform and opening-up policy initiated in 1978. However, the rapid economic growth has caused serious environmental damage, such as depletion of natural resources, climate change, and severe ecological degradation in China [3,4]. The energy industry's environmental practices play a crucial role in solving environmental problems. For example, just 32 energy enterprises from the Global 500 emitted 31 percent of the world's total greenhouse gases, including the emissions from the use of their products [5]. China consumes the second-most energy of any country in the world, and Chinese 
energy enterprises' environmental responsibility practices receive a lot of attention. However, their overall environmental performance is worrying. Several incidents at Chinese energy enterprises that involved environmental damage have been reported, such as Zijin Mining Copper Mine's acid leakage in 2010, cadmium pollution accident in Longjiang Rive in 2012, and Tianji Company's aniline leakage in 2013 [3]. Accidents at energy enterprises have a more disastrous impact on regional pollution than those of other industries. Therefore, Chinese energy enterprises must assume environmental responsibility, beginning with the most fundamental practices such as restoring the damage to the environment in a timely fashion and keeping damage to the environment to a minimum. Because the Chinese legal framework for environmental protection is still weak [6], it is important that energy enterprises proactively assume environmental responsibility to support the harmonious coexistence of people and nature. Furthermore, as more Chinese energy enterprises implement the "going global" strategy, it is also necessary for the firms that pursue PCER to gain legitimate status. The "going global" strategy means that China adapts to economic globalization, make full use of the international and domestic markets, optimize the allocation of resources, actively pursues international cooperation and competition, and promotes reform and development by opening up [7]. In the context of globalization, firms are confronted with complex institutional demands [8] and can obtain legitimacy acceptance by proactively assuming CER [9]. Corporate leaders are generally inclined to assume CER and are willing to positively promote environmental protection, yet their response to implementing PCER may be influenced by the relationship between PCER and Corporate Financial Performance (CFP). Therefore, it was the main purpose of this research to clarify the relationship between PCER and CFP.

The study extends and contributes to the previous literature in 3 ways. First, many previous studies have focused on reactive corporate environmental responsibility, but we know comparatively little about how corporations proactively and voluntarily assume environmental responsibility [10]. Using the Golden Bee database, we constructed an index of PCER and analyzed the influence of PCER on the studied firms' financial performance. Golden Bee database was provided by the Golden Bee Development Center that is the first (Corporate Social Responsibility (CSR) research institution to publish reference books on how to prepare CSR reports in China [11]. Second, we examined the effect of PCER on CFP in China (an emerging market). Previous literature in this field has examined development in developed countries, specifically the Australia, United States, and Belgium $[2,12,13]$. However, the center of global economic growth is turning to emerging markets [14]. Even small developing countries such as Trinidad and Tobago, have become key international players in the energy industry trading with developed countries [15]. Large developing countries typically garner the most attention [16]. Some large developing countries, such as Russia, India, Brazil, and China, have obtained extremely higher economic growth than ever before from 1991 to 2010 [17]. The above four large developing countries have been listed in the top 10 countries according to economic size since the year 2000. China is a leading and increasingly influential developing country. China is undergoing a transition from a planned economy to a market economy, and the institutional environment is weak in which legal is enforced inefficiently and incomplete [4]. China's marketplace provides a useful sociopolitical context with much variation that is relevant to the relationship between PCER and CFP. Third, we focused on the relationship between PCER and CFP in the energy industry. There is existing research on the effect of CER on CFP in a variety of industries, such as the service sector [18], manufacturing [3], and financial services sector [19]. The energy industry has the strongest impact in the risk reduction of environmental accidents and waste, in the reuse of by-products in production, and the restoration of a contaminated environment [12]. Therefore, it is imperative to examine the effect of PCER on energy firm's financial performance.

In the Section 2, this paper provides a literature review and our hypotheses. Then, it describes the data sample and the empirical methods. The study conducts the empirical analysis in the energy industry and provides the empirical results in the Section 4. In the Section 5, the findings and their implications are summarized. In the Section 6, the study provides conclusions and future research. 


\section{Literature Review and Hypotheses}

There are many different definitions and classifications of CSR based on different theories. According to the categories of corporate social responsiveness, CSR can be divided into Proactive CSR and Reactive CSR [2,20]. In addition, from the view of stakeholder theory, CER is a dimension of CSR [21] and it is a key social issue of CSR based on the Wartick and Cochran's (1985) polices [22,23]. Integrating the above opinions, proactive CER (PCER) and reactive CER are two different kinds of CER according to the responsiveness on CER. Reactive CER is a non-voluntary practice and just expend the minimum level required for non-voluntary regulatory compliance [24]. PCER, as the environmental dimension of proactive corporate social responsibility, focuses on pollution prevention, eco-efficiency, innovation, and environmental leadership [13]. PCER is usually characterized by adopting an internationally compliant environmental management system to minimize a firm's ecological impact [2].

\subsection{PCER and CFP}

Although there were few studies that focused exclusively on the relationship between PCER and CFP, some researchers found a relationship between CER (or Corporate Social Responsibility (CSR)) and CFP. There is still some controversy over the idea that corporate environmental responsibility is beneficial to financial performance. However, there are some key theories to support the passive relationship or the positive relationship between PCER and CFP, and there are shown in Table 1.

Waddock and Graves [25] proposed that the environmental protection activities of a firm will spend its financial resources and improve its costs involved cannot be offset by the benefits from the environmental protection activities based on the bargaining theories. Brammer, et al. [26] measured the implementation degree of CER based on the number of reports on an environment system's management. In addition, they examined the influence of CER on corporate performance and concluded that CER has a negative effect on it. Ambec and Lanoie [27] challenged this idea and argued that CER can lead to better CFP; they analyzed the mechanism involved in each of the following channels to improve environmental practices: differentiating products, selling pollution-control technology, better access to certain markets, cost of material, energy, and labor and services. El Ghoul, et al. [28] also proposed that the cost of equity capital is lower when firms have higher corporate environmental responsibility in manufacturing firms. Resource-based-views can be used to strategically examine the extent that firms engage in environmental responsibility. Aragon-Correa, et al. [29] found environmental relative proactive CSR positively affects CFP using a resource-based perspective. Flammer [30] posited that CER generates new, competitive resources; he also concluded that it causes a significant increase in the stock price of a firm based on an event study around the announcement of corporate news from 1980 to 2009. Shiu and Yang [31] suggested that CER practice provides insurance-like effects for CFP in the face of negative events.

CER as a signal can decease the impact of information asymmetry [32]. Wei, Shen, Zhou and Li [4] used a dataset of 238 Chinese firms and found that CER practices, as a signal, have positive effects on business.Wei, et al. [33] analyzed 126 listed firms in China and concluded that high reputation firms can assuage firm value loss. Using a social identity theory perspective of CER signals, Farooq, et al. [34] analyzed the mechanisms through which the internal and external CER influenced employee identification and the subsequent outcomes. They proposed that CER actions enhance perceived respect, which both influence employee organizational identification and its subsequent outcomes in different ways.

Neo-institutional theory may provide key insights into the relationship between CER and CFP. Neo-institutionalism emphasizes the nature and variety of the institutional process and regards CER practices as a result of legitimacy [9]. In the internal and external context of taken-for-granted institution, firms need assume various practices to cope with the legitimacy demands from the institutional environment [15]. Correspondingly, in order to maintain firms' legitimacy, firms have to respond to environmental problems along their business operations [8]. Legitimacy means that 
the actions of an entity are proper, appropriate or desirable in accordance with norm, value, beliefs and definitions within a socially constructed system [16,35]. If firms do not behave in a manner deemed to be socially correct, they will lose legitimacy [36]. Legitimacy can help the company gain unrestricted access to markets, provide the company with access to resources, and improve its long-term profit $[11,37]$.

Because PCER is often characterized by adopting internationally compliant environmental management systems, it helps to build a firm's legitimacy and credibility in the international system. There are also some authors who analyzed the relationship between PCER and CFP based on technological innovation. Environmental responsibility is a major driver of firm innovation and affects firm performance [38]. Torugsa, O'Donohue and Hecker [2] found that innovation resulting from PCER can improve production efficiencies and increase the firm's financial performance by using data from sample of 171 small and medium enterprises in Australia. Chang [39] used data from the Taiwanese manufacturing industry and found that PCER can enhance green product innovation performance. Therefore, we suggested the following:

Hypothesis 1: PCER positively influences CFP.

Table 1. The main supporting theories for the relationship between proactive corporate environmental responsibility (PCER) and CFP.

\begin{tabular}{|c|c|c|c|}
\hline $\begin{array}{l}\text { The Supporting } \\
\text { Theory }\end{array}$ & Standpoint & Definition of the Theory & $\begin{array}{l}\text { Influencing Mechanism on the Relationship } \\
\text { Between PCER and CFP }\end{array}$ \\
\hline $\begin{array}{l}\text { Bargaining } \\
\text { theory }\end{array}$ & $\begin{array}{l}\text { Negative } \\
\text { relationship }\end{array}$ & $\begin{array}{l}\text { This theory keeps the firm not as } \\
\text { a production function but as a governance } \\
\text { structure and admits that Minimizing } \\
\text { transaction costs is the best governance } \\
\text { structure [40]. }\end{array}$ & $\begin{array}{l}\text { The environmental protection activities of } \\
\text { a firm will spend its financial resources and } \\
\text { improve its costs involved cannot be offset by } \\
\text { the benefits from the environmental protection } \\
\text { activities }[3,25] \text {. }\end{array}$ \\
\hline signaling theory & $\begin{array}{l}\text { Positive } \\
\text { relationship }\end{array}$ & $\begin{array}{l}\text { Signaling process begin to work, only if it } \\
\text { receive the signal what it is looking for [ } 42] \text {. }\end{array}$ & $\begin{array}{l}\text { Firm send a signal of CER practice and } \\
\text { therefore gain legitimate status [4]. }\end{array}$ \\
\hline $\begin{array}{l}\text { Neo-institutional } \\
\text { theory }\end{array}$ & $\begin{array}{l}\text { Positive } \\
\text { relationship }\end{array}$ & $\begin{array}{l}\text { Neo-institutionalism emphasizes the nature } \\
\text { and variety of the institutional process and } \\
\text { regards CER practices as a result of } \\
\text { legitimacy [9]. }\end{array}$ & $\begin{array}{l}\text { CER practice help firm obtain legitimacy and } \\
\text { make the company gain unrestricted access to } \\
\text { markets, provide the company with access to } \\
\text { resources, and improve its long-term profit } \\
{[11,37] \text {. }}\end{array}$ \\
\hline
\end{tabular}

\subsection{The Influence of Private Ownership on the Relationship Between the PCER and CFP}

There has been some research about ownership. For example, Hong [44] proposed that private entrepreneurs can increase their influence in the Chinese economic spheres through contributing to charitable causes based on an analysis of the 5 main private business groups in China. Using a 1995 survey of 2879 Chinese private entrepreneurs, Ma and Parish [45] suggested that at least the 1990s private enterprises exchanged corporate donations for social status and legitimacy. Wang and Qian [46] used data from Chinese firms from 2001-2006 to propose that firm philanthropy has a stronger effect on CFP for privately-owned firms than for state-owned firms

Ownership is a key factor that we must consider when analyzing the influencing factors of Chinese firms' financial performance Wang, et al. [47]. In the early 1990s, the Chinese government began privatizing reforms at state-owned firms and actively promoted the development of privately owned firms. State-owned firms do not worry about legitimacy as much as the leaders of privately-owned 
firms [11]. Comparatively, privately-owned firms wanted to maintain their legitimacy in the eyes of the public and government. Legitimacy can help companies obtain access to unrestricted access to markets, gain resources, and improve their long-term profit [11,37]. Engaging with the principles of CER was a response to policy signals, and it showed that they positively accept government initiatives. Hence, some firms took a more proactive role, going above and beyond what was required by the standards, in improving sustainable environment [2]. $\mathrm{Hu}$, et al. [48] found that private and foreign equity offered a greater incentive to corporate performance and correspondingly boosted financial performance. Moderators describe the conditions under which CER practice has effect on outcomes, while mediators presents the underlying mechanisms of why CSR initiatives influence outcomes [49,50]. This study concerns the relationship between the PCER and CFP under the condition of private ownership, therefore we regard private ownership as a moderator between PCER and CFP. Thus, we suggested the following:

Hypothesis 2: Private ownership enhances the relationship between the relationship of PCER and CFP.

\subsection{The Influence of Past Performance on the Relationship Between the PCER and CFP}

A firm's stakeholders are generally interested in PCER, yet they may be constrained by the firm's financial situation. When firms are in financial distress, they are not able to assume more responsibility [51]. Highly profitable firms are more readily able to take a pragmatic approach to legitimacy such as better-quality products to consumers and fewer emission of wastes and poisonous gases to the community [35,52]. If a firm performs better, it will have more financial and physical resources to engage in PCER practices and subsequently promote the improvement of the firm's financial performance.

The literature shows that leadership also contributes to PCER engagement [53]. However, the extent that top leadership is concerned with CER is influenced by the firm's financial performance [54]. However, top leadership faces the vexing reality that they must balance the relationship between rival financial and societal demands. Therefore, we suggested the following:

Hypothesis 3: The positive relationship between PCER and CFP increases with the level of the firm's past financial performance.

\section{Research Methods}

\subsection{Sample and Data}

We examined data from 44 energy enterprises distributed in 5 different industries, shown in Table 2. We applied China's national industry classification to our samples. There were 11 enterprises in coal mining and washing, 2 enterprises in oil and gas mining, 2 enterprises in ferrous metal mining, 8 enterprises in non-ferrous metal mining, and 21 enterprises in electric, heating, natural gas, and water production and supply. Among these, there were 2 privately-owned and 42 state-owned enterprises. The data sources used were the Golden Bee CSR reporting rating database and the China Stock Market and Accounting Research (CSMAR) database. The Golden Bee's indicators of CSR are different from The Global Reporting Initiative (GRI) Standards. The requirement of GRI standards are much stricter to the developing country's firms. For example, the acquisition of the environmental information's disclosure needs a lot of manpower and cost. According to the Golden Bee's statistical results, there is just 21.21\% CSR reports of China's firms based on GRI4 in 2017. CSR standards must be instructive and be adapted to the development level of region. The Golden Bee's indicators of CSR are constructed combining with the national conditions of China. They are divided into 12 sub-indexes based on stakeholder theory and each sub-index has its own detailed index system. Golden Bee's CSR rating database is becoming more popular with Chinese firms [55]. 
Data base and estimation method are the key factors in the empirical research. Samples data are mainly divide into cross-sectional data and longitudinal data in the relative research of CSR. Aguinis and Glavas [49] concluded that there is primarily tendency to the cross-sectional data at a time in the present research on CSR that cannot provide causal interpretation. Furthermore, these cross-sectional data mainly originate from questionnaire and its reliability is sometimes a concern [56,57]. CER practice and its outcomes both place over time and longitudinal data can provide this condition. The 44 sample firms' data of the research from 2009 to 2014 provide data security on causal analysis.

Table 2. Industry and Ownership Distribution.

\begin{tabular}{ccccc}
\hline Industry Description & Industry Code & State-Owned & Privately-Owned & $\begin{array}{c}\text { Sum of State-Owned and } \\
\text { Privately-Owned }\end{array}$ \\
\hline Coal Mining and Washing & B06 & 11 & 1 & 12 \\
Oil and Gas Mining & B07 & 2 & 0 & 2 \\
Ferrous Metal Ore Mining & B08 & 2 & 0 & 2 \\
Non-Ferrous Metal Ore Mining & B09 & 6 & 0 & 6 \\
Electric Power and Heating Power & D44 & 21 & 1 & 22 \\
Generation & & 42 & 2 & 44 \\
Total & &
\end{tabular}

\subsection{Measures}

\subsubsection{Dependent Variable}

The ROA is the return on assets and is recognized as the best performance measure to use in China [58]. Because there is often a lag between corporate social and environmental behaviors and their impact on CFP [59], the effect of the PCER on CFP was evaluated in terms of the subsequent ROA.

\subsubsection{Independent Variable}

A lack of measurement options for CER is a major shortcoming in CER research [60]. The study constructed the PCER index, which is different from the index of reactive corporate environmental responsibility. The PCER was measured by 5 items based on the previous literature and the Golden Bee database. The index included training in environmental protection consciousness, training funds for environmental protection, advocating employee participation in environmental public welfare activities, the pursuit of 0 emissions during production and application, and special funds to support the conservation and utilization of resources. The proactive environmental responsibility score range was $(0,5)$.

\subsubsection{Moderating Variables}

The "Private ownership" was given a dummy code of 0 if the ultimate owner of a firm was State-owned; otherwise, it was assigned a value of 1 . Past financial performance was calculated as the ROA lagging by 1 year $[46,61]$.

\subsubsection{Control Variables}

The firm size was assessed as the natural $\log$ of the total assets, which is a key variable in analyzing the relationship between social and financial performance [46]. We included 12 industry dummies to control the possible differences in PCER engagement across industries. Reporting age was the number of years since the firm released a CSR report.

\section{Results}

The summary statistics for the variables is shown in Table 3. These variables are the ROA, PCER, firm size, ownership, industry dummy, and reporting age.

The structural equation modeling (SEM) and regression analysis are the two mainstream analysis methods in empirical analysis. SEM is a statistical method and is not a method for causal analysis and 
regression analysis is an causal analysis [2]. Therefore, the research performs multivariate regression to examine the influence of PCER on CFP.

The form of the model is as follows:

$$
\begin{aligned}
& R O A_{i t}=\alpha+\beta_{1} \cdot R O A_{i t-1}+\beta_{2} \cdot \text { Firm size }+\beta_{3} \cdot P C E R_{t-1}+\beta_{4} \cdot P C E R_{i t-1} \cdot R O A_{i t-1}+\beta_{5} \cdot P C E R_{i t-1} \cdot \text { Ownership }+ \\
& +\beta_{6} \cdot \text { Ownership }+\beta_{7} \cdot \text { Industry dummy }+\beta_{8} \cdot \text { Ownership }+\beta_{7} \cdot \text { Reporting age }+\varepsilon
\end{aligned}
$$

where $\alpha$ is the intercept. $\beta_{1}$ to $\beta_{7}$ denotes the regression coefficients, and $\varepsilon$ denotes the stochastic shocks.

Table 3. Descriptive Statistics for the Variables.

\begin{tabular}{cccccc}
\hline Variables & Obs & Mean & SD & Min. & Max. \\
\hline ROA & 254 & 0.045 & 0.069 & -0.691 & 0.2085 \\
PCER & 190 & 1.105 & 1.048 & 0 & 4 \\
Firm size & 216 & 23.822 & 1.729 & 20.416 & 28.482 \\
Private ownership & 254 & 0.047 & 0.212 & 0 & 1 \\
Reporting age & 264 & 6.136 & 0.945 & 3 & 9 \\
\hline
\end{tabular}

The correlations for the variables are provided in Table 4 . It shows that the ROAt-1, PCERt-1, firm size, and ownership have a positive correlation with the ROA. Reporting age has a negative correlation with the ROA.

Table 4. Correlations for the Variables.

\begin{tabular}{cccccc}
\hline Variables & $\mathbf{1}$ & $\mathbf{2}$ & $\mathbf{3}$ & $\mathbf{4}$ & $\mathbf{5}$ \\
\hline ROA & 1 & & & & \\
ROAt-1 & 0.7035 & & & & \\
PCERt-1 & 0.1472 & 0.0154 & & & \\
Firm size & 0.0804 & 0.1091 & 0.153 & & \\
Private ownership & 0.1514 & 0.1843 & 0.0909 & -0.0426 & \\
Reporting age & -0.0535 & -0.1317 & -0.1172 & -0.136 & 0.0163 \\
\hline
\end{tabular}

Five models were developed in our research, and these are shown in Table 5. Model 1 was the control model. We introduced the previous ROA, Firm size, Private ownership, Industry dummy, and Reporting age as the control variables. Model 2 was used to test PCERt's influence on the ROA. Other variables included the intercepts and control variables, such as the previous ROA, Firm Size, Private ownership, Industry dummy, and Reporting age. Model 2 shows that PCERt has no significant influence on CFP in the energy industry. Model 3 was used to test Hypothesis 1. It showed that the PCER t-1 has an important influence on the CFP. In Model 4, we assessed the moderating effects (Hypothesis 2 and Hypothesis 3) of ownership and past financial performance on the CFP. The R2 values of the models ranged from $0.095 \%$ to $0.444 \%$. Model 4 shows that the inter-coupling effect between PCERt-1 and private ownership has positive moderating effects on the firm's financial performance. In this way, Hypothesis 2 is also supported by our results. The results for Model 4 indicate that the final performance does not have a moderating effect on the PCER and CFP. Consequently, we rejected Hypothesis 3, which was contrary to our expectations. What needs to be mentioned is that Private ownership was concluded in above each model, but its coefficient was omitted in each regression.

Because we focus on the energy industry characterized with monopoly, the number of firms is comparably not so much. On the other hand, it is not mandatory to issue CSR reports so that the companies' samples become less that could be used in the research. Among of the 44 firms, the biggest size is Petro China Company limited with total assets of 2340 billion Yuan and the small size is Chongqing Fuling Electric Power Industrial Company limited with total assets of 736 million Yuan. These 44 firms provide representations of China's energy firms. 
This samples data is longitudinal data. Longitudinal data can been used to explain the causality of the correlations [4]. In the previous study, there are large data sets that include hundreds of firms, but some of them consist of cross-sectional data. Aguinis and Glavas [49] concluded that there are primarily tendency to the cross-sectional data at a time in the present research on CSR that cannot provide causal interpretation. Furthermore, these cross-sectional data mainly originate from questionnaire and its reliability is sometimes a concern [56,57]. CER practice and its outcomes both place over time and longitudinal data can provide this condition. The 44 sample firms' data of the research from 2009 to 2014 provide data security on causal analysis. Therefore, we are sure that the empirical result based on 143 firm-year observations of longitudinal data is worth convincing.

Table 5. Regression of PCER on CFP.

\begin{tabular}{|c|c|c|c|c|c|}
\hline Variables & Model 1 & Model 2 & Model 3 & Model 4 & Model 5 \\
\hline ROAt-1 & $\begin{array}{c}0.374^{* * *} \\
(2.86)\end{array}$ & $\begin{array}{c}0.450 * * * \\
(3.26)\end{array}$ & $\begin{array}{c}0.411^{* * *} \\
(2.69)\end{array}$ & $\begin{array}{c}0.569 * * * \\
(2.90)\end{array}$ & $\begin{array}{c}1.599 * * \\
(2.47)\end{array}$ \\
\hline Firm Size & $\begin{array}{l}-0.024 * \\
(-1.80)\end{array}$ & $\begin{array}{l}-0.017 \\
(-1.16)\end{array}$ & $\begin{array}{l}0.004 \\
(0.24)\end{array}$ & $\begin{array}{l}0.001 \\
(0.05)\end{array}$ & $\begin{array}{l}0.025 \\
(0.68)\end{array}$ \\
\hline PCERt & & $\begin{array}{l}-0.004 \\
(-1.23)\end{array}$ & & & \\
\hline PCERt-1 & & & $\begin{array}{l}0.007^{*} \\
(1.78)\end{array}$ & $\begin{array}{l}0.009^{*} \\
(1.92)\end{array}$ & $\begin{array}{l}0.054^{* *} \\
(2.03)\end{array}$ \\
\hline PCERt- 1 * ROAt-1 & & & & $\begin{array}{l}-0.084 \\
(-1.52)\end{array}$ & $\begin{array}{l}-0.383 \\
(-1.15)\end{array}$ \\
\hline PCERt- 1 * Private ownership & & & & $\begin{array}{c}0.040 \text { ** } \\
(2.26)\end{array}$ & $\begin{array}{l}0.043^{*} \\
(1.79)\end{array}$ \\
\hline Industry Dummy & YES & YES & YES & YES & YES \\
\hline Reporting age & YES & YES & YES & YES & YES \\
\hline _cons & $\begin{array}{l}0.612 * \\
(1.88)\end{array}$ & $\begin{array}{l}0.443 \\
(1.23)\end{array}$ & $\begin{array}{l}-0.074 \\
(-0.19)\end{array}$ & $\begin{array}{l}-0.009 \\
(-0.02)\end{array}$ & \\
\hline r2_a & 0.095 & 0.152 & 0.455 & 0.444 & \\
\hline Observations & 168 & 151 & 143 & 143 & 127 \\
\hline Sargan test & & & & & 0.536 \\
\hline
\end{tabular}

We examined the potential endogeneity in the empirical study. There were 3 possible reasons for endogeneity in this work. First, there may have been a measurement error in the PCER data. Second, we may have omitted variables that were correlated with both the PCER and CFP, which may not be included on the right side of Equation (1). Third, there may be mutual causality between the dependent variable and independent variables. In order to mitigate the endogeneity issue, we used the dynamic system GMM method in Model 5. We used PCERt, the first lag of the log of the total assets and the first lag of the log of the employees' number as the instrument variables. The $p$-value of the Sargan test was 0.536 . This result indicates that over-identifying restrictions for GMM were accepted, and the instrumental variables were exogenous. We found a statistically significant effect of PCER on CFP in Chinese energy industry.

\section{Discussion}

\subsection{Theoretical Contributions}

First, this study extends the CSR literature. Although there is some accumulation of the literature on CSR and CER, few studies focus on PCER. PCER is a voluntarily environmental practice and a kind of CER which go beyond regulatory requirement. In the context of globalization, the strict division of environmental responsibility has become vague and PCER become more and more important. The study constructed PCER indicators based on the previous literature and availability of data. 
In addition, the study explored the influence of PCER on CFP which directly affect the firm's CER strategy. It proposed the hypothesis that PCER has a positive effect on CFP based on the resource-based theory, signaling theory and neo-institutional theory. The results strongly support the hypothesis and the study enriches the relative literature of PCER.

Second, this study extends property rights theory by investigating the private ownership's influence on the relationship between PCER and CFP in the context of weak institution system. With the reform of property rights, private property rights obtained legitimate status in 2004 in China. Although they keep booming development, China's privately-owned firms have experienced social and political discriminations, and are faced with the challenge to the legitimacy in their own markets [62]. When privately-owned firms choose to internationalize, legitimacy is still a challenge that they must be accepted. CSR practice is an effective strategy to obtain legitimate status [63] and legitimacy can help firms to access market resources and competitive advantages. This empirical result testified that privately-owned firms has the positive effect on the relationship between the PCER and CFP in a weak institutional situation.

In addition, our results indicate that past performance does not have a moderating effect on the relationship between PCER and CFP. We think this result may be mainly related to our samples. Table 1 shows that there are 42 state-owned energy firms and only 2 privately-owned energy firms. State-owned firms can allocate key business resources such as licenses, subsidies, project approvals, and permits [62]. Compared with privately-owned firms, state-owned firms obtained more benefits in the form of government backing and resources, and in general, were less responsive to changes in their financial positions [11]. In this way, past performance has no positive moderating effect on the relationship between the PCER and CFP for most state-owned energy firms. Second, privately owned energy firms may voluntarily pay to implement PCER for legitimacy, neglecting their financial position. Third, a firm's mission is an important predictor of CSR engagement [49,64]. Firms affiliated with environmentally sensitive industries have been paid more attention in environmental responsibility practices [65], which may also lead them to consider financial position less important.

This study extends the CER literature by identify PCER, construct constructed PCER indicators and explore the relationship between PCER and CFP. This study also extends property rights perspective by exploring the private ownership's influence on the relationship between PCER and CFP in weak institutional system. These findings on the relationship between PCER and CFP have key implications for other emerging economics, such as Russia, India, Brazil and Niger, where institutional systems are not yet well established [4].

\subsection{Policy Implications}

Our research yields value to government policy makers. If governmental regulations and guidelines for promoting firms' environmental responsibility practices are ambiguous or uncertain, there may be non-comparable and uneven environmental responsibility practices among firms. For this reason, the central governments must provide more detailed guidance to encourage PCER, for example, implement strict punishment mechanism to negative behavior that affects environment. In addition, the central government should actively promote the internationalization of domestic enterprises, because returnee directors, executives and foreign investor introduce advanced institution into China [14]. Internationalization can help firms facilitate the process of legalization and access more global resources.

It is worth mentioning that provincial government play an key role in facilitating laws and policy enforcement in China $[3,66]$. Therefore, the central government must stimulate provincial government to strictly enforce relative environmental regulations and vigorously promote "going global" strategy.

\subsection{Managerial Implications}

Our analysis demonstrated that PCER and CFP are not mutually exclusive. We content that PCER practice can help firms gain legitimacy and access resources and support from government. Firms' 
leaders should engage in PCER strategy for accessing more munificent and efficient foreign market. Adoption of PCER is necessary to make improvements in the company's financial performance in the next year. Therefore, energy enterprises may actively identify and adopt those elements of the related PCER. Based on the above empirical results, enterprises should be active in the training employees in environmental protection consciousness and the pursuit of 0 emissions during production and application. In addition, special funds to support the conservation and utilization of resources should be established, which can decrease the production cost and increase green product innovation that enhances firms' competitive advantages. The more self-regulated enterprises can gain more return.

The results show that private ownership has a positive influence on the relationship between PCER and CFP. State-owned firms benefit from government backing and resources, and their actions, including proactive environmental responsibility practices, are relatively less constrained by their financial position [11]. Privately-owned enterprises are still a relatively new organizational form in China and suffer from a lack of economic legitimacy. Private enterprises want to survive and thrive in the Chinese economy, they must actively implement PCER to obtain legitimacy and political access. By implementing PCER, privately-owned enterprises can obtain goodwill from government regulators and get access to resources from the government, which facilitates CFP.

In addition, this research is focused on a specific industry-energy industry and the empirical result has become more pertinent. Industry associations have played a growing role in emerging market [15]. Developing country can construct a "green alliances" based on industry associations and jointly engage in PECR strategy. It may more efficiently aggregate bad impression owing to weak institutional conditions of their home countries and create positive externalities.

\section{Conclusions}

The study shows that an energy enterprise's PCER has a positive effect on CFP even after controlling for issues related to endogeneity and omitted variables, and further showed that private ownership has positive influence on the relationship between PCER and CFP. The study extends CSR literature and property rights theory. The study has also generated value on policy practice. Government should implement institutions system and promote the internationalization of domestic enterprises. These empirical results provide a reference for the environmental responsibility practices of domestic and foreign firms. Firms in developing countries are faced with ethical dilemmas because the legal system is still imperfect in developing countries. The experiences and development of the PCER practices in China have important implications for other developing nations' economies. Firms should emphasize PCER practices to take wider environmental concerns into consideration.

There were some limitations to this study. First, there were only 2 privately-owned firms among the 44 sample firms, which may be related to the nature of the energy industry itself. However, in order to further enhance the credibility of our results, we need to further increase the sample capacity of enterprises especially in privately-owned enterprises. Another limitation of the study is that there were an insufficient number of mechanisms for analyzing the PCER's effect on financial performance.

Based on the above, we identified several areas of future research. First, we will examine the influence of other potential factors that affect the relationship between PCER and CFP. For example, different local governments may have different regulations and guidelines. We will study the local government's effect on the relationship between PCER and CFP. Second, the underlying mechanisms by which PCER affects CFP will be further elucidated. In addition, we will utilize all of the necessary information disclosed by the listed firms to have sufficient data to expand the study of the relationship between PCER and CFP.

Acknowledgments: This research was supported by the National Key Research and Development (R\&D) Program of China (No. 2016YFC0701800) (No. 2016YFC0701808) and the National "12th Five-Year" Science and Technology Program of China (No. 2014BAL05B06). The work described in this paper was also funded by the National Natural Science Foundation of China (NSFC) (Grant No. 71390522, No. 71671053, No. 71271065, No. 71771067). 
Author Contributions: Ying Jiang conceived the study and wrote this manuscript. Xiaolong Xue commented for the overall study, and provided valuable suggestions. Weirui Xue joined the further revision.

Conflicts of Interest: The authors declare no conflict of interest.

\section{References}

1. Torugsa, N.A.; O'Donohue, W.; Hecker, R. Capabilities, proactive csr and financial performance in smes: Empirical evidence from an Australian manufacturing industry sector. J. Bus. Ethics 2012, 109, 483-500. [CrossRef]

2. Torugsa, N.A.; O'Donohue, W.; Hecker, R. Proactive CSR: An empirical analysis of the role of its economic, social and environmental dimensions on the association between capabilities and performance. J. Bus. Ethics 2013, 115, 383-402. [CrossRef]

3. Wong, C.W.Y.; Miao, X.; Cui, S.; Tang, Y. Impact of corporate environmental responsibility on operating income: Moderating role of regional disparities in China. J. Bus. Ethics 2016. [CrossRef]

4. Wei, Z.L.; Shen, H.; Zhou, K.Z.; Li, J.J. How does environmental corporate social responsibility matter in a dysfunctional institutional environment? Evidence from China. J. Bus. Ethics 2017, 140, 209-223. [CrossRef]

5. Moorhead, J.; Nixon, T. Global 500 Greenhouse Gas Report: The Fossil Fuel Energy Sector; Thomson Reuters: Toronto, ON, Canada, 2015; pp. 1-6.

6. Firth, M.; Wang, K.; Wong, S.M.L. Corporate transparency and the impact of investor sentiment on stock prices. Manag. Sci. 2015, 61, 1630-1647. [CrossRef]

7. Chai, H. Policy framework and mode choice of going global strategy. J. Int. Econ. Coop. 2003, 5, 15-19.

8. Baumann-Pauly, D.; Scherer, A.G.; Palazzo, G. Managing institutional complexity: A longitudinal study of legitimacy strategies at a sportswear brand company. J. Bus. Ethics 2016, 137, 31-51. [CrossRef]

9. Yin, J.L. Institutional drivers for corporate social responsibility in an emerging economy: A mixed-method study of Chinese business executives. Bus. Soc. 2017, 56, 672-704. [CrossRef]

10. Abbott, W.F.; Monsen, R.J. On the measurement of corporate social responsibility: Self-reported disclosures as a method of measuring corporate social involvement. Acad. Manag. J. 1979, 22, 501-515. [CrossRef]

11. Marquis, C.; Qian, C.L. Corporate social responsibility reporting in China: Symbol or substance? Organ. Sci. 2014, 25, 127-148. [CrossRef]

12. Sharma, S.; Vredenburg, H. Proactive corporate environmental strategy and the development of competitively valuable organizational capabilities. Strateg. Manag. J. 1998, 19, 729-753. [CrossRef]

13. Buysse, K.; Verbke, A. Proactive environmental strategies: A stakeholder ma perspective. Strategic management journal. Strateg. Manag. J. 2003, 24, 453-470. [CrossRef]

14. Cumming, D.; Hou, W.X.; Lee, E. Business ethics and finance in greater China: Synthesis and future directions in sustainability, CSR, and fraud. J. Bus. Ethics 2016, 138, 601-626. [CrossRef]

15. Shah, K.U.; Rivera, J.E. Do industry associations influence corporate environmentalism in developing countries? Evidence from Trinidad and Tobago. Policy Sci. 2013, 46, 39-62. [CrossRef]

16. Shah, K.U.; Rivera, J.E. Export processing zones and corporate environmental performance in emerging economies: The case of the oil, gas, and chemical sectors of Trinidad and Tobago. Policy Sci. 2007, 40, $265-285$. [CrossRef]

17. Wang, M.C.; Fang, C.R.; Huang, L.H. The coexistence of high unemployment and good economic performance in large open developing countries. Rev. Int. Econ. 2012, 20, 767-780. [CrossRef]

18. Sharma, S.; Aragon-Correa, J.A.; Rueda-Manzanares, A. The contingent influence of organizational capabilities on proactive environmental strategy in the service sector: An analysis of North American and European ski resorts. Can. J. Adm. Sci. 2007, 24, 268-283. [CrossRef]

19. Jo, H.; Kim, H.; Park, K. Corporate environmental responsibility and firm performance in the financial services sector. J. Bus. Ethics 2015, 131, 257-284. [CrossRef]

20. Carroll, A.B. A three-dimensional conceptual model of corporate performance. Acad. Manag. Rev. 1979, 4, 497-505.

21. Jamali, D. A stakeholder approach to corporate social responsibility: A fresh perspective into theory and practice. J. Bus. Ethics 2008, 82, 213-231. [CrossRef]

22. Carroll, A.B. Corporate social resposibility: Evolution of a definitional construct. Bus. Soc. 1999, 38, $268-295$. [CrossRef] 
23. Garriga, E.; Mele, D.N. Corporate social responsibility theories: Mapping the territory. J. Bus. Ethics 2004, 53, 51-71. [CrossRef]

24. Groza, M.D.; Pronschinske, M.R.; Walker, M. Perceived organizational motives and consumer responses to proactive and reactive CSR. J. Bus. Ethics 2011, 102, 639-652. [CrossRef]

25. Waddock, S.A.; Graves, S.B. The corporate social performance-financial performance link. Strateg. Manag. J. 1997, 18, 303-319. [CrossRef]

26. Brammer, S.; Brooks, C.; Pavelin, S. Corporate social performance and stock returns: UK evidence from disaggregate measures. Financ. Manag. 2006, 97-116. [CrossRef]

27. Ambec, S.; Lanoie, P. Does it pay to be green? A systematic overview. Acad. Manag. Perspect. 2008, $23,45-62$.

28. El Ghoul, S.; Guedhami, O.; Kim, H.; Park, K. Corporate environmental responsibility and the cost of capital: International evidence. J. Bus. Ethics 2016, 31, 1-27. [CrossRef]

29. Aragon-Correa, J.A.; Hurtado-Torres, N.; Sharma, S.; Garcia-Morales, V.J. Environmental strategy and performance in small firms: A resource-based perspective. J. Environ. Manag. 2008, 86, 88-103. [CrossRef] [PubMed]

30. Flammer, C. Corporate social responsibility and shareholder reaction: The environmental awareness of investors. Acad. Manag. J. 2013, 56, 758-781. [CrossRef]

31. Shiu, Y.M.; Yang, S.L. Does engagement in corporate social responsibility provide strategic insurance-like effects? Strateg. Manag. J. 2017, 38, 455-470. [CrossRef]

32. Zerbini, F. CSR initiatives as market signals: A review and research agenda. J. Bus. Ethics 2017, 146, 1-23. [CrossRef]

33. Wei, J.C.; Ouyang, Z.; Chen, H.P. Well known or well liked? The effects of corporate reputation on firm value at the onset of a corporate crisis. Strateg. Manag. J. 2017, 38, 2103-2120. [CrossRef]

34. Farooq, O.; Rupp, D.E.; Farooq, M. The multiple pathways through which internal and external corporate social responsibility influence organizational identification and multifoci outcomes: The moderating role of cultural and social orientations. Acad. Manag. J. 2017, 60, 954-985. [CrossRef]

35. Suchman, M.C. Managing legitimacy: Strategic and institutional approach. Acad. Manag. Rev. 1995, 20, 571-610.

36. Sethi, S.P. A conceptual framework for environmental analysis of social issues and evaluation of business response patterns. Acad. Manag. Rev. 1979, 4, 63-74.

37. Oliver, C.; Holzinger, I. The effectiveness of strategic political management: A dynamic capabilities framework. Acad. Manag. Rev. 2008, 33, 496-520. [CrossRef]

38. Varadarajan, R. Innovating for sustainability: A framework for sustainable innovations and a model of sustainable innovations orientation. J. Acad. Mark. Sci. 2017, 45, 14-36. [CrossRef]

39. Chang, C.H. Proactive and reactive corporate social responsibility: Antecedent and consequence. Manag. Decis. 2015, 53, 451-468. [CrossRef]

40. Williamson, O.E. Transaction cost economics: How it works; where it is headed. Economist 1998, 146, $23-58$. [CrossRef]

41. Russo, M.V.; Fouts, P.A. A resource-based perspective on corporate environmental performance and profitability. Acad. Manag. J. 1997, 40, 534-559. [CrossRef]

42. Connelly, B.L.; Certo, S.T.; Ireland, R.D.; Reutzel, C.R. Signaling theory: A review and assessment. J. Manag. 2011, 37, 39-67. [CrossRef]

43. Mael, F.A.; Ashforth, B.E. Loyal from day one: Biodata, organizational identification, and turnover among newcomers. Pers. Psychol. 1995, 48, 309-333. [CrossRef]

44. Hong, Z. Mapping the evolution and transformation of the new private entrepreneurs in China. J. Chin. Political Sci. 2004, 9, 23-42. [CrossRef]

45. Ma, D.L.; Parish, W.L. Tocquevillian moments: Charitable contributions by Chinese private entrepreneurs. Soc. Forces 2006, 85, 943-964. [CrossRef]

46. Wang, H.L.; Qian, C.L. Corporate philanthropy and corporate financial performance: The roles of stakeholder response and political access. Acad. Manag. J. 2011, 54, 1159-1181. [CrossRef]

47. Wang, Q.; Wong, T.J.; Xia, L.J. State ownership, the institutional environment, and auditor choice: Evidence from China. J. Account. Econ. 2008, 46, 112-134. [CrossRef]

48. Hu, Y.F.; Song, M.; Zheng, H. The impact of ownership structural reform on performance of China's enterprises. Social sciences in China. Soc. Sci. China 2006, 4, 50-65. 
49. Aguinis, H.; Glavas, A. What we know and don't know about corporate social responsibility a review and research agenda. J. Manag. 2012, 38, 932-968.

50. Baron, R.M.; Kenny, D.A. The moderator-mediator variable distinction in social psychological research: Conceptual, strategic, and statistical considerations. J. Pers. Soc. Psychol. 1986, 51, 1173-1182. [CrossRef] [PubMed]

51. Blanco, B.; Guillamon-Saorin, E.; Guiral, A. Do non-socially responsible companies achieve legitimacy through socially responsible actions? The mediating effect of innovation. J. Bus. Ethics 2013, 117, 67-83. [CrossRef]

52. Park, S.; Sine, W.D.; Tolbert, P.S. Professions, organizations, and institutions: Tenure systems in colleges and universities. Work Occup. 2011, 38, 340-371. [CrossRef]

53. Shin, Y.; Sung, S.Y.; Choi, J.N.; Kim, M.S. Top management ethical leadership and firm performance: Mediating role of ethical and procedural justice climate. J. Bus. Ethics 2014, 129, 43-57. [CrossRef]

54. Dooley, R.S.; Lerner, L.D. Pollution, profit, and stakeholders: The constraining effect of economic performance on CEO concern with stakeholder expectations. J. Bus. Ethics 1994, 13, 701-711. [CrossRef]

55. Noronha, C.; Tou, S.; Cynthia, M.I.; Guan, J.J. Corporate social responsibility reporting in China: An overview and comparison with major trends. Corp. Soc. Responsib. Environ. Manag. 2013, 20, 29-42. [CrossRef]

56. Shimshack, J.P.; Ward, M.B. Regulator reputation, enforcement, and environmental compliance. J. Environ. Econ. Manag. 2005, 50, 519-540. [CrossRef]

57. Shah, K.U. Strategic organizational drivers of corporate environmental responsibility in the Caribbean hotel industry. Policy Sci. 2011, 44, 321-344. [CrossRef]

58. Wang, H.L.; Choi, J.P.; Li, J.T. Too little or too much? Untangling the relationship between corporate philanthropy and firm financial performance. Organ. Sci. 2008, 19, 143-159. [CrossRef]

59. Hendricks, K.B.; Singhal, V.R. The effect of product introduction delays on operating performance. Manag. Sci. 2008, 54, 878-892. [CrossRef]

60. Grewatsch, S.; Kleindienst, I. When does it pay to be good? Moderators and mediators in the corporate sustainability-corporate financial performance relationship: A critical review. J. Bus. Ethics 2017, 145, 383-416. [CrossRef]

61. Ruf, B.M.; Muralidhar, K.; Brown, R.M.; Janney, J.J.; Paul, K. An empirical investigation of the relationship between change in corporate social performance and financial performance: A stakeholder theory perspective. J. Bus. Ethics 2001, 32, 143-156. [CrossRef]

62. Li, H.B.; Meng, L.S.; Wang, Q.; Zhou, L.A. Political connections, financing and firm performance: Evidence from Chinese private firms. J. Dev. Econ. 2008, 87, 283-299. [CrossRef]

63. Marano, V.; Tashman, P.; Kostova, T. Escaping the iron cage: Liabilities of origin and CSR reporting of emerging market multinational enterprises. J. Int. Bus. Stud. 2017, 48, 386-408. [CrossRef]

64. Bansal, P. From issues to actions: The importance of individual concerns and organizational values in responding to natural environmental issues. Organ. Sci. 2003, 14, 510-527. [CrossRef]

65. Zeng, S.X.; Xu, X.D.; Yin, H.T.; Tam, C.M. Factors that drive Chinese listed companies in voluntary disclosure of environmental information. J. Bus. Ethics 2012, 109, 309-321. [CrossRef]

66. Ding, S.J.; Jia, C.X.; Wu, Z.Y.; Yuan, W.L. Environmental management under subnational institutional constraints. J. Bus. Ethics 2016, 134, 631-648. [CrossRef]

(c) 2018 by the authors. Licensee MDPI, Basel, Switzerland. This article is an open access article distributed under the terms and conditions of the Creative Commons Attribution (CC BY) license (http://creativecommons.org/licenses/by/4.0/). 